„Bohemistyka” 2019, nr 4, ISSN 1642-9893

Marek CHLEBOWSKI

DOI: $10.14746 /$ bo. 2019.4 .4

Uniwersytet im. Adama Mickiewicza

\title{
Anglicyzmy leksykalne i ich derywaty w języku czeskim na podstawie gazety „Mladá fronta Dnes”
}

Keywords: Czech language, Mladá fronta Dnes, Anglicisms, Czech-English language contacts

Słowa kluczowe: język czeski, „Mladá fronta Dnes”, anglicyzmy, czesko-angielskie kontakty językowe

\section{Abstract}

The object of the article are 435 lexical items - anglicisms and their derivatives (used a total of 3124 times). The material is derived from seven extensive issues of Mladá fronta Dnes published in November 2009. The lexical units represent, among others, the following semantic fields: sport (128 units), music and subcultures (40 units), transport and construction ( 25 units), economy and business (24 units) and mass media (24 units). Single items account for about $40 \%$ of the total.

Przedmiotem artykułu jest 435 haseł leksykalnych - anglicyzmy i derywaty od anglicyzmów (użyte łącznie 3124 razy). Materiał pochodzi z siedmiu obszernych numerów gazety „Mladá fronta Dnes” z listopada 2009 r. Jednostki leksykalne reprezentują między innymi następujące pola znaczeniowe: sport (128 haseł), muzyka i subkultury (40 haseł), transport i budownictwo (25 hasel), ekonomia i handel (24 hasła), środki masowego przekazu (24 hasła). Około 40\% wszystkich haseł stanowią hapaxlegomena.

\section{Uwagi wstępne}

Język czeski, podobnie jak inne języki słowiańskie, dokumentuje anglicyzmy leksykalne i utworzone od nich derywaty już przed XX w. Wpływy angielszczyzny nasilają się stopniowo od początku XX w., a zwłaszcza od połowy XX w., ale wzmożona ekspansja pożyczek angielskich ma miejsce (jak w innych językach słowiańskich) dopiero od przełomu lat osiemdziesiątych i dziewięćdziesiątych XX w. 
Zapożyczenia angielskie kilku ostatnich dziesięcioleci dokumentuje leksykografia czeska (m.in. słowniki: Hubáček 2003, Kraus 2007, Martincová 1998-2004, Rejzek 2001). Prezentują je również, opisują ich strukturę i oceniają z punktu widzenia kultury językowej autorzy opracowań językoznawczych (np. Hampl 2014; Imioło 2001; Kořenský 2003; Michalska 2010; Svobodová 2007; Szczepańska 2004a, 2004b, 2009; Waszakowa 2006).

Obecnie brakuje prac, w których wszechstronnie by analizowano zasoby anglicyzmów w języku konkretnego utworu literackiego, w określonym korpusie tekstowym (np. w wylosowanych próbkach tekstowych) czy w wybranych gazetach lub periodykach czeskich. Postanowiłem tę lukę choćby częściowo wypełnić. Wyekscerpowałem pożyczki angielskie i utworzone od nich derywaty $z$ siedmiu numerów gazety „Mladá fronta Dnes” (wraz z dodatkiem lokalnym Liberca) $z$ okresu od 3.11.2009 r. do 10.11.2011 r.

Ze względu na to, iż głównym celem tej gazety jest przedstawienie najważniejszych wydarzeń w kraju i ze świata oraz ich skomentowanie, możemy tutaj znaleźć informacje z wielu dziedzin (polityka, życie społeczne, ekonomia, sport, kultura) oraz różne gatunki dziennikarskie (artykuł, wywiad, komentarz, felieton). To powoduje, że możemy prześledzić, w jakich sferach życia anglicyzmy odgrywają najważniejszą rolę. Wynik ekscerpcji to 3124 poświadczenia użycia anglicyzmów (i ich derywatów), które tworzą 435 hasel: 356 rzeczowników, 58 przymiotników, 13 czasowników i 8 przysłówków. Potwierdza się opinia, że większość zapożyczeń z języka angielskiego to rzeczowniki.

Celem niniejszego artykułu jest opis zgromadzonych zapożyczeń Nie będę się zajmować problematyką adaptacji formalnej (graficznej, fonetyczno-fonologicznej i morfologicznej) oraz semantycznej (przeniesienie, rozszerzenie czy zawężenie znaczenia). Zagadnienia te są już dosyć dobrze opracowane w bohemistycznej literaturze naukowej. Materiał leksykalny przedstawię w ramach pól znaczeniowych. W lingwistyce polskiej teorię pól znaczeniowych wnikliwie przedstawili m.in. Danuta Buttler (1967), Wiesław Miodunka (1980, 1989), Walery Pisarek (1967) oraz Ryszard Tokarski (1984 i prace późniejsze).

W analizach pól znaczeniowych stosuje się m.in. metodę semową (por. np. pracę Elżbiety Mańczak-Wohlfeld 1992). Jednak na ogół badacze korzystają z uproszczonej wersji pola znaczeniowego, wyróżniając kategorie semantyczne i zakresy pojęciowe bez odwoływania się do teorii semowej, np. E. Mańczak-Wohlfeld (1995, s. 68-73) bierze pod uwagę 45 pól. W moim artykule nawiązuję do grup znaczeniowych, które zaproponowała Halina Koneczna (1936-1937). Kolejność ich prezentacji zależy od liczby poświadczonych w nich haseł należących do różnych części mowy - zapożyczeń właściwych i derywatów utworzonych od zapożyczeń.

Do anglicyzmów zaliczam również wyrazy, które od dawna traktuje się jako internacjonalizmy, np. bar, box, film, klub, motor, park, radar, rádio, telefon, televize. Trudno jest oddzielić anglicyzmy od internacjonalizmów (często pochodzenia angielskiego). Jeśli anglicyzm jest obecny przynajmniej w kilku językach, to jest już właściwie internacjonalizmem. Jednak nie istnieją przekonujące kryteria pozwalające zaliczyć konkretną pożyczkę z angielskiego do pogranicza anglicyzmów i internacjonalizmów czy już do internacjonalizmów.

\section{Analiza semantyczna i statystyczna anglicyzmów w gazecie} "Mladá fronta Dnes"

Jak już wspomniałem, w zebranym materiale znajduje się 435 haseł pochodzenia angielskiego, które dokumentują 3124 poświadczenia i które zostały podzielone na 24 pola znaczeniowe. Ich udział w poszczególnych polach semantycznych przedstawia tabela 1 .

Niekiedy zaliczenie jakiegoś wyrazu do danej kategorii semantycznej może budzić zastrzeżenie, ale takich wątpliwości nie da się uniknąć. Niektóre pożyczki bowiem należą do pośrednich grup znaczeniowych. W dalszej części artykułu (jak również w tabeli) kolejność analizy poszczególnych pól znaczeniowych uzależniono od liczby reprezentujących je haseł. 
Tab. 1. Udział anglicyzmów w poszczególnych polach znaczeniowych

\begin{tabular}{|c|l|c|c|c|c||}
\hline \multirow{2}{*}{ Lp. } & \multirow{2}{*}{ Nazwa pola znaczeniowego } & \multicolumn{2}{|c|}{$\begin{array}{c}\text { Liczba hasel } \\
\text { wyrażona }\end{array}$} & \multicolumn{2}{c|}{$\begin{array}{c}\text { Liczba poświadczeń } \\
\text { wyrażona }\end{array}$} \\
\cline { 3 - 6 } & & liczbowo & \% & liczbowo & $\%$ \\
\hline 1. & Sport & 128 & 29,4 & 1467 & 46,9 \\
\hline 2. & Muzyka i subkultury & 40 & 9,2 & 54 & 1,7 \\
\hline 3. & Transport i budownictwo & 25 & 5,7 & 118 & 3,8 \\
\hline 4. & Ekonomia i handel & 24 & 5,5 & 138 & 4,4 \\
\hline 5. & Środki masowego przekazu & 24 & 5,5 & 223 & 7,1 \\
\hline 6. & Życie społeczne & 21 & 4,8 & 134 & 4,3 \\
\hline 7. & Film i literatura & 20 & 4,6 & 143 & 4,6 \\
\hline 8. & Turystyka i wypoczynek & 17 & 3,9 & 165 & 5,3 \\
\hline 9. & Urządzenia audiowizualne & 16 & 3,7 & 48 & 1,5 \\
\hline 10. & Rozrywka & 14 & 3,2 & 64 & 2,0 \\
\hline 11. & Moda i ubiory & 14 & 3,2 & 45 & 1,4 \\
\hline 12. & Komputery i Internet & 13 & 3,0 & 231 & 7,4 \\
\hline 13. & Jedzenie i picie & 12 & 2,8 & 16 & 0,6 \\
\hline 14. & Komunikacja telefoniczna & 11 & 2,5 & 83 & 2,6 \\
\hline 15. & Praca i nauka & 10 & 2,2 & 75 & 2,4 \\
\hline 16. & Wojsko, wojna, broń & 10 & 2,2 & 43 & 1,4 \\
\hline 17. & Motoryzacja & 10 & 2,2 & 13 & 0,5 \\
\hline 18. & Medycyna i zdrowie & 6 & 1,4 & 11 & 0,4 \\
\hline 19. & Policja i przestępczość & 5 & 1,2 & 8 & 0,3 \\
\hline 20. & Narkotyki & 4 & 1,2 & 7 & 0,2 \\
\hline 21. & Rolnictwo & 3 & 0,7 & 13 & 0,4 \\
\hline 22. & Zoologia & 3 & 0,7 & 13 & 0,4 \\
\hline 23. & Polityka & 2 & 0,5 & 9 & 0,3 \\
\hline 24. & Nauki ścisłe i technika & 435 & 100 & 3124 & 100 \\
\hline & \multicolumn{1}{|c|}{ RAZEM } & & 3 & 0,1 \\
\hline & & 3 & & \\
\hline
\end{tabular}

Anglicyzmy mają najczęściej postać wyrazów pojedynczych (prostych lub złożonych), np. tým, basketbal; czasem są to połączenia wyrazowe, np. noise cancelling, lub skrótowce, np. $A H L, N B A$. Poja- wiają się także derywaty, tworzone już na gruncie języka docelowego, np. fanoušek, parkoviště, tramvaják.

Niewielka część materiału to skrótowce, np. AHL (American Hockey League), ATP (Association of Tennis Prefessionals), mające nominalny charakter i dlatego włączane do kategorii rzeczowników. Wymienione skrótowce oraz $F 1, M L B, N B A$, WTA itd. pierwotnie oznaczały tylko instytucje, tj. były nazwami własnymi. Ich semantyka jednak się rozszerzała. Później poszerzono ich znaczenie i używano również jako określenia rodzajów zawodów sportowych. Być może reprezentują pogranicze nazw własnych i pospolitych. Innego typu skrótowce (np. NATO, PVC, SMS) zwykle zalicza się do angielskich zapożyczeń leksykalnych (Mańczak-Wohlfeld 2010). Również one są podstawami słowotwórczymi wielu derywatów, np. esemeska, esemeskový, esemesovat.

W wypadku czasowników sufiksacja jest warunkiem koniecznym adaptacji morfologicznej (por. SMS - esemesovat), również prawie zawsze sufiksy otrzymują zapożyczone przymiotniki (z wyjątkiem zapożyczeń przymiotników nieodmiennych, np. cool), przysłówki zaś tworzy się od odpowiednich zapożyczeń przymiotnikowych. Czasem jednak nie jest pewne, czy przymiotnik został zapożyczony bezpośrednio z angielskiego, czy też utworzony od zapożyczenia rzeczownikowego.

W kilku wypadkach można mieć wątpliwość, czy konkretne hasła (np. kód, turista, turistika) są anglicyzmami, czy np. germanizmami. Sądzę, że kód obecnie kojarzy się raczej z angielskim źródłem językowym (o wyrazach turista i turistika szerzej w podrozdziale 8. Turystyka i wypoczynek).

\subsection{Sport}

To pole znaczeniowe reprezentuje 128 zapożyczeń $(29,6 \%$ w stosunku do całości), które zostały poświadczone 1467 razy (47\% w stosunku do wszystkich wyekscerpowanych anglicyzmów). Niektóre hasła (przynajmniej 58) odnoszą się do kilku dyscyplin sportowych lub mają charakter ogólnosportowy. Oto anglicyzmy tej grupy: 
antidopingový (1), aut (1), bek 'pozycja obrońcy' (3), b-tým 'druga drużyna w zespole' (2), derby (7), driblér (1), dribling (1), fanklub (1), fanoušek (55), fanouškovský (1), faul (4), finiš (2), forhend 'uderzenie piłki wewnętrzną stroną rakiety' (1), forvard 'pozycja napastnika' (2), freestyle (3), freestylový(1), gól (85), gólman 'bramkarz' (16), gólmanový (1), gólový (1), klub (64), klubový (16), kouč 'szkoleniowiec, trener' (37), koučovat (3), kurt 'pole gry do tenisa i squasha' (1), mečbol 'piłka decydująca o zwycięstwie w siatkówce lub tenisie' (2), mitink (1), ofsajd 'przewinienie w piłce nożnej i w hokeju na lodzie' (2), penalta 'rzut karny w piłce nożnej' (4), play-off 'w sporcie faza pucharowa rozgrywek' (9), rekord (12), rekordně 'rekordowo' (1), rekordni (10), set (3), skaut/scout (2), skórovat 'zdobywać punkty lub bramki' (1), sport (72), sportovat (3), sportováni (3), sportovec (19), sportoviště (3), sportovkyně (2), sportovně 'sportowo' (2), sportovní (53), start (15), startovat (5), superstart (1), šampion 'zwycięzca imprezy rangi mistrzowskiej’ (11), šampionát (14), šampionka (1), trénovat (16), trénováni (2), tréner (103), trénink (15), tréninkový (4), tým 'drużyna' (126), týmový (2), volej 'w piłce nożnej i tenisie uderzenie $\mathrm{z}$ powietrza' (4)

Inne jednostki leksykalne odnoszą się tylko do konkretnych dyscyplin sportowych. Chodzi o: p iłk ę no ż n ą: fotbal $101 \mathrm{r}$, fotbalový (85), fotbalista $40 \mathrm{r}$, fotbálek (1), fotbalistka (1), stoper (5) i h o k e j $\mathrm{n}$ a $1 \mathrm{odz}$ i e : AHL (1)-American Hockey League, bodyček 'w hokeju na lodzie zatrzymanie przeciwnika ciałem' (2), hokej (63), hokejista (38), hokejistka (1), hokejka (33), NHL - National Hockey League, power-play (1). Wiele słów, występujących w badanym materiale, można włączyć do następujących podgrup: s p o r ty druż y n o w e (oprócz piłki nożnej i hokeja na lodzie): americký fotbal (1), baseball (3), baseballista (1), baseballový (2), basketbal (9), basketbalistka (4), basketbalový (4), draft 'sposób wybierania nowych zawodników do lig zawodowych' (1), florbal 'halowa odmiana hokeja na trawie' (6), florbalový (2), florbalista (1), florbalistka (1), homerun 'w baseballu najwyżej punktowane uderzenie' (2), NBA (7) - National Basketball League, NFL (2) - National Football League, smečar 'pozycja atakującego w siatkówce' (2), volejbal (10), volejbalista (7), volejbalový (2); s porty zi mowe (oprócz hokeja na lodzie): bobista 'bobsleista' (2), curling 'gra polegająca na umieszczeniu kamieni w środku okręgu' (1), skiaerál 'miejsce do uprawiania narciarstwa' (3), snowboard (1), snowboarding (1), snowboardista (1), Summer GP (2), - Summer Grand Prix (2); s p or t y m o t o r o w e: autokros (1), enduro 'rodzaj sportu motorowego' (5), F1 (37) - Formule 1 (16), GP (6) - Grand Prix GP 2 (9) - Grand Prix (2), formule 'rodzaj wyścigów samochodowych' (6), motocyklista (5), motocyklový (5), motokros (8), motokrosař (2), motosport (3), rallyekros 'zawody samochodowe na torze' (2), superlicence 'dokument uprawniający do startów w wyścigach Formuły 1' (2); k o 1 a r s t w o: crossový (7), cyklokros (1), cyklokrosařka 'kobieta uprawiająca kolarstwo przełajowe' (1), cyklokrosařský (2), mountainbikový 'mountain bike - rywalizacja kolarzy w terenie górzystym' (1); t e n i s: ATP (2) - Association of Tennis Professionals, brejk 'szybki kontratak' (2), grandslam 'turniej wielkiego szlema' (1), grandslamový (3), servis (13), tenis (18), tenisový (9), tenista (6), tenistka (6), WTA 'cykl damskich turniejów tenisowych' (1).

\subsection{Muzyka i subkultury}

Grupę tę reprezentuje 40 haseł (9,2\% wszystkich haseł) poświadczonych 54 razy (1,7\% wszystkich poświadczeń). Występują tutaj aż 33 hasła raz poświadczone (ponad 80\% wszystkich haseł tego pola znaczeniowego). Wyrazy odnoszące się do ró żn y c h s ty ló w m u zycznych i zachowań subkulturowych to: bigbít (1), blues (1), boogie (1), boogie rock (1), EMO 'emotional (EMO) - subkultura młodzieżowa' (2), emo punker 'przedstawiciel kultury EMO' (1), gospel 'rodzaj muzyki wykonywanej głównie w kościołach' (1), gospelový (1), hardcorový (1), hip-hop (1), indie-rockový (1), jazzový (1), jazzově (1), muzikál (2), muzikálový(1), pop (2), popový(1), punk (1), punker (1), rap (1), raper (3), rapování (1), rockový (1), rocker (1), rokenrol (1), rokenrolový (1), trash-popový (1), trip-hop (1), triphopový (1). Inne hasła w tej grupie dotyczą r y n k u w y d a w n i - 
czego: diskografie (1), CD/cédéčko/cédéčka (6), LP (1) - long play, single (1) Wyrazy nazywające wykonawcó w, dźw i ę ki oraz nowe tendencje w muzyce: frontman 'lider grupy muzycznej' (3), shouter 'muzyk umiejący śpiewać z kapelą bez użycia mikrofonu'(1), DJ(3), dýdžejský(1), bas (1), mixování (1), remix (1).

\subsection{Transport i budownictwo}

To pole stanowi 25 leksemów (5,7\% wszystkich haseł) w 118 użyciach (3,8\% wszystkich użyć). Z angielszczyzny do języka czeskiego zapożyczono m.in. tramvaj (12) i metro (8) oraz utworzono od nich derywaty tramvaják (2) oraz metrák (2) Mamy tutaj również leksykę związaną z p r z e w o z e m t a k s ó w k o w y m: taxik(3), taxikár̆ (6), taxikáření (1) oraz z p a r k o w a n i e m: parkoviště (9), parkovat (3), parkování (5) Słownictwo kolejowe reprezentuje tylko vagón (2). Słowniki różnych języków europejskich nie traktują jako anglicyzmu słowa autobus. Ale tak chyba jednak jest, por.:

AUTOBUS XX-1, nm. fr., autobus 1907 (podobno nowotwór paryski, ale wcześniej jednak w USA, ang.-amer. autobus 1895) (Bańkowski 2000, s. 20).

Nie włączam słowa autobus do mojego materiału, ale za anglicyzmy uznaję wyrazy, w których usunięto komponent auto- i dodano nowy element: cyklobus (4), minibus (1), skibus (2)

Inne podgrupy znaczeniowe to $\mathrm{t} \mathrm{rans} \mathrm{p}$ or $\mathrm{t} 1 \mathrm{ot} \mathrm{nic} \mathrm{z}$ : aerolinie (5), aerolinka (10), charterový (2), pilot (12); t r a n s p o r t w o d $\mathrm{n}$ y: dok (1), jachta 'jacht' (3). Związek z transportem i komunikacją odzwierciedlają wyrazy: kontejner (1), motel (1), tunel (11).

Z budownictwe m kojarzą się: panel (11) oraz bojler (1) 'podgrzewacz wody'.

\subsection{Ekonomia i handel}

24 hasła (5,5\% wszystkich haseł) wystąpiły w 138 użyciach (4,4\% wszystkich poświadczeń). Charakterystyczną grupę tworzą wyrazy: dolar (28), byznys (18), byznysmen (4), lobbing (7), lobbista (11), lobbovat (5), lobby (1), market (2) - hypermarket (2) - supermarket (4), marketing (4), marketingový(5), marketingově (2) Pozostałe anglicy- zmy z tego pola znaczeniowego dotyczą następujących grup tematycznych: ży c i e g o s p od a r c z e: holding (6), holdingový (1), downtown 'biznesowe centrum miasta' (1); s fer a u bezp i e c z en: asistance 'współpraca; ubezpieczenie' (4), asistenční (9); r y n e k g i e ł d o w y: komodita 'towar w obrocie giełdowym' (8), komoditni (1); b a n k o w o ś ć: interbanking (1), PIN (8); r e k l a m a: $\operatorname{logo}(3)$, billboard (3).

\section{5. Środki masowego przekazu}

Materiał tego pola obejmuje 24 hasła (5,5\% wszystkich haseł) w 223 użyciach (7,1\% wszystkich poświadczeń). Hasła televize (73) i televizní (35) są poświadczone łącznie 108 razy (prawie 49\% poświadczeń w tej grupie). W zebranym materiale występują też inne wyrazy dotyczące te le w i zj i: digitalizace (3), digitální (7), HD 'system odbioru sygnału telewizyjnego' (2) - high definition, $L C D$ (1) - liquid crystal display. Znacznie rzadziej pojawiało się słownictwo pochodzenia angielskiego związane $\mathrm{z} \mathrm{r}$ a di e m, np. FM rádio (1), FM tuner (1), rádio (3), rádiokomunikace (4), rádiový (1) Rzadziej można spotkać leksykę angielską dotyczącą p r a s y: diár̆ 'kalendarz kieszonkowy' (2), reportér (15), reportérka (5), reportovat (2).

Słowo video pojawiło się aż 23 razy. Służy ono czasem do tworzenia hybryd językowych, np. videokonference (1), videoprenos (1), videosestřih (1), videozáznam (3). Jeszcze częściej jest udokumentowane hasło média (33 razy, 15\% użyć w tej grupie), które jest podstawą derywatów reprezentujących różne części mowy: medializovat (1), médiálně (1), médiální (4).

\section{6. Życie społeczne}

21 haseł $(4,8 \%$ wszystkich haseł) jest poświadczonych w 134 przykładach użyć (4,3\% wszystkich użyć). Odzwierciedlają one m.in. problematykę psychologiczna, socjologiczna i ekologiczną. Najczęściej występują słowa bonus (53 razy, 40\% poświadczeń w polu) oraz limit (37 razy, 28\% poświadczeń). Można by je zakwalifikować również do innych kategorii (np. handel), ale wydaje się, że ich umiesz- 
czenie w tym zbiorze jest zasadne. Wybrane wyrazy określają r ó ż n e o s o by ży c i a s p ołec zne go: gay (1), gentelman (1), jeliman 'człowiek naiwny' (1), lady (1), lídr 'lider' (20), lord (2), outsider (2), sir (1), squater 'osoba zajmująca nielegalnie opuszczone mieszkanie' (14), teenager (1), teenagerka (1), VIP (2). Warto zwrócić uwagę na słowa nazywające różne aspekty życia związane z f u n k c j o n o w a n i em s połe czeńs twa: bizární 'cudaczny, szalony' (5), bo$\mathrm{om} / \mathrm{bum}$ 'nagły wzrost zainteresowania lub odgłos wybuchu' (4), flirtovat (1), handicap 'wyrównanie szans' (8), sexuálni (4), šok (6), šokovat (5), trans 'stan euforii' (1).

\subsection{Film i literatura}

W tym polu pojawia się 20 haseł $(4,6 \%$ wszystkich haseł $) \mathrm{w} 143$ użyciach (4,6\% wszystkich użyć). Najczęściej pojawiało się słowo film (69); są też udokumentowane derywaty: filmár (5), filmeček (1), filmotéka (1), filmování (1), filmovat (1), filmově (1), filmový (15). Wymienione wyrazy stanowią 65\% użyć leksyki w tej grupie.

Pozostałe hasła związane z fi $1 \mathrm{~m}$ e $\mathrm{m}$ to: béčkový 'o filmie wyprodukowanym za małe pieniądze' (2), horor (6), klip (7), love story (1), remake 'film oparty na wcześniejszym pierwowzorze' (1), sci-fi (2) science fiction, seriál (18), thriller (7), trailer 'zapowiedź filmu lub programu telewizyjnego w postaci wyciętych fragmentów' (1), videoklip (1) Rzadziej występują anglicyzmy dotyczące $\mathrm{k}$ s i ą ż k i: booklet 'broszura' (1) oraz detektivka (2) (wyraz pojawiający się częściej w kontekście książki niż kinematografii)

\subsection{Turystyka i wypoczynek}

W zgromadzonym materiale jest 17 haseł (3,9\% wszystkich haseł) w 165 poświadczeniach (5,3\% wszystkich użyć). Víkend (47) i víkendový (5) stanowią około 30\% użyć wszystkich anglicyzmów tej kategorii semantycznej. Turista (23), turistika (3) i turistický (9) to $20 \%$ poświadczeń pożyczek angielskich w zakresie wypoczynku i turystyki.

Wyrazy turista i turistika zaliczam do zapożyczeń angielskich, choć ich źródłem najpierw był niewątpliwie język niemiecki. Chodzi tutaj o wtórne oddziaływanie angielskiego. Nawiązuję w tym wypadku do poglądu R. Filipovicia (1990, s. 333), który słowo turistika i pokrewne w chorwackim zalicza do anglicyzmów.

Inne podkategorie znaczeniowe interesujących nas wyrazów to: m i e j c e w y p o c zy n k u: kemp (34), park (8), singltrek 'ścieżka do uprawiania kolarstwa górskiego' (7), singltrekový (2), snowpark 'miejsce uprawiania sportów zimowych' (1); spr zęt słu żąc y do uprawiania aktywności fizycznej: cyklotrenažér 'rower treningowy' (2), expander 'rodzaj sprzętu do ćwiczeń fizycznych' (2), ministepper 'przyrzad gimnastyczny' (1), stepper (3), trenažér 'urządzenie umożliwiające szkolenie sportowców' (15); s pę $\mathrm{dzan}$ i e wolne g o c zas u:fitness (2), spinning 'forma aktywności fizycznej (np. jazda na rowerze treningowym w takt muzyki)' (1).

\subsection{Urządzenia audiowizualne}

Tutaj mamy 16 haseł (3,7\% wszystkich haseł) w 48 poświadczeniach (1,5\% wszystkich poświadczeń). Nazwy dzisiaj już p r z e s ta rzałych urządzeń do odtwarzania dźwię ku to: diktafon (3), diskman (1), walkman (1); nazwy n o w e g o s p r z ę t u odtw a r za ją c e g o dźw i ę k: MP3 (14), MP3man (1), MP4 (5); inne anglicyzmy: displej (7), in-air 'rodzaj słuchawek' (1), megafon (1), mikrofon (3), noise cancelling 'funkcja, która pozwala na wyciszenie dźwięków z zewnątrz' (1), videokamera (1), videorekordér (1). Poświadczone są nazwy urządzeń wielofunkcyjnych, dzięki którym można odtwarzać muzykę lub oglądać filmy: iPood (1), iPood Touch (2), PMP (5).

\subsection{Rozrywka}

Wyekscerpowałem 14 haseł (3,2\% wszystkich hasel) w 64 użyciach ( $2 \%$ wszystkich użyć). Są to: celebrita (1), festival (24) (około $32 \%$ użyć w tej grupie), hit (18), hitovka (3), hitparada (2), idol (1), miss (2), show (4), one man show (1), one woman show (1), party/párty (2), pornopřiběh (1), stryptýz (1), trik (3). 


\subsection{Moda i ubiory}

Również to pole tworzy 14 haseł (3,2\% wszystkich haseł) w 45 użyciach $(1,4 \%$ wszystkich użyć). Sa to słowa ogólnie odnoszace się do m od y i u b i or ó w: design (7), designer (1), designový (5), trend (12); stylu w modzie: image (2), retrostyl (1), salonni 'przymiotnik od saloon' (1), sexy (1) (chodzi o strój seksi), ultramoderní (1), unisexový (1); $\mathrm{nazw}$ t kan in: coolmax 'materiał służacy do produkcji odzieży termoaktywnej' (1), thermoligh (1); n a z w fry $\mathrm{z}$ u r: dred (1); r o d z a j u u b i or u: dres (10).

\subsection{Komputery i Internet}

Jak wiadomo, większość terminologii komputerowej w różnych językach świata wywodzi się z języka angielskiego. W analizowanych numerach „Mladá fronta Dnes” wystąpiło 13 anglicyzmów (2,9\% wszystkich haseł) w 231 poświadczeniach (7,4\% wszystkich użyć). Dwa wyrazy internet (71) i internetový (26) są udokumentowane 97 razy, co stanowi 30\% użyć słownictwa komputerowego.

W języku czeskim powszechnie używa się słowa počitač 'komputer'. W źródle naszego materiału pojawił się wyraz computer (3), ale tylko w jednym artykule. Język czeski ma też - w odróżnieniu od innych języków (również słowiańskich) - terminy rodzimego pochodzenia, jak np. obrazovka (zamiast ang. monitor), klavesnice (zamiast ang. keyboard), základni deska (zamiast ang. motherboard). Inne anglicyzmy dotyczące komunikacji internetowej, budowy oraz oprogramowania komputera, poświadczone $\mathrm{w}$ analizowanej gazecie, to: čip (4), data (7), datový (43), harddisk (1), klik (1), server (31), software (1), web (20), on-line (16), portál (7).

\subsection{Jedzenie i picie}

W tym polu znajduje się 12 haseł (2,7\% wszystkich haseł) w 16 poświadczeniach $(0,6 \%$ wszystkich poświadczeń). Odnoszą się one do: $\mathrm{n}$ a z w j e d z e n i a: biftek (1), džem (1), hamburgr (1), sendvič (2), steak (3); na zw napojów: Coca-Cola (1), džus (1), jogurt (1), koktejl (1); na zw lo kali oraz u sł u g gas tro n o m i c z n y ch: bar (1), catering (1), fast food (2).

\subsection{Komunikacja telefoniczna}

Spośród 11 haseł (2,5\% wszystkich haseł) w 83 użyciach $(2,6 \%$ wszystkich użyć) telefon (27) i derywaty: telefonát (1), telefonicky 'telefonicznie' (2), telefonni (4), telefonovat (1) to pożyczki udokumentowane 35 razy (około $42 \%$ wszystkich użyć w grupie). Inne wyrazy związane z telefonią to: call center (1), esemeska (3), SMS (18), infolinka (14), mobil (10), telekomunikační (2).

\subsection{Praca i nauka}

W zgromadzonym materiale znalazło się 10 haseł $(2,2 \%$ wszystkich haseł) w 75 poświadczeniach (2,4\% wszystkich użyć) dotyczących pracy i nauki. Dominuje słowo test (25) (33\% użyć w tej grupie) i jego derywaty: testováni (2), testovat (6); tematycznie zbliżone jest określenie psychotest (1). Do tego pola znaczeniowego zaliczyłem również hasła: boss (6), džob (1), e-learning (1), management 'jedna z nauk ekonomicznych' (10), manažer (22), manažerský (1).

\subsection{Wojsko, wojna i broń}

Również w tym polu znajduje się 10 hase $(2,2 \%$ wszystkich haseł $)$ w 43 poświadczeniach $(1,4 \%$ wszystkich użyć). Najczęściej wystąpił wyraz masakr (19) (43\% użyć w tej grupie), który pojawia się w kontekście rozważań o wojnie i oznacza masowe mordy. Resztę słownictwa związanego $\mathrm{z}$ wojskowością i bronią można pogrupować następująco: urządzenia wojskowe: radar (9), nazwa oddziału: komando (2), infrastruktura wojskowa: kontingent (4), fight camp (3), transportér (1), mustang (1), b r o n i s tr z e le c k i j: kolt (2), revolver (1), o d d a ni e strzału: šot (1).

\subsection{Motoryzacja}

Jest to trzecie pole, w którym znajduje się 10 haseł (2,2\% wszystkich hasel), jednak mniej poświadczonych razy użytych, bo 13 razy ( $0,5 \%$ wszystkich poświadczeń). Anglicyzmy tego pola to e le m e n ty w y posażenia s a m o ch o du: $A B S$ (1) - Anti-Lock Braking System, airbag 'element systemu bezpieczeństwa w samochodzie' (2), hatchback 'typ nadwozia samochodowego' (1), imobilizér 'za- 
bezpieczenie przed samoczynnym uruchomieniem samochodu' (1), $L P G$ (1) - Liquefied Petroleum Gas; na z w y s a m o chodów i i n ny ch pojazdów: džíp (1), pickup (1), skútr (1); w y razy doty czące handlu sa moch od a m i:autosalon (1), dealer (3).

\subsection{Medycyna i zdrowie}

Jest to jedno z mniej reprezentowanych pól. Znajduje się tutaj 6 haseł $(1,4 \%$ wszystkich haseł $)$ w 11 poświadczeniach $(0,4 \%$ wszystkich użyć). Są to: adrenalin (2), AIDS (2) oraz HIV (1), e-health 'technologia służąca do wspomagania działań związanych z ochroną zdrowia' (1), stres (4), stresovaně (1).

\subsection{Policja i przestępczość}

Anglicyzmy odnoszace się do policji i przesteppzości to 5 haseł $(1,2 \%$ wszystkich hasel) w 8 poświadczeniach $(0,3 \%$ wszystkich użyć). Są to: bodyguard 'osobisty ochroniarz' (1), detektiv (2), gang (3), gangster (1), inspektor (1).

\subsection{Narkotyki}

W tym polu pojawiły sie zaledwie 4 hasła ( $1,2 \%$ wszystkich haseł) w 5 poświadczeniach $(0,2 \%$ wszystkich użyć). Materiał: crystal meth 'N-metylowa pochodna amfetaminy' (1), joint 'wyrób przypominający wyglądem papierosa, wypełniony suszem z marihuaną, zwykle pomieszaną z tytoniem' (1), LSD 'substancja psychoaktywna' (2) Lysergic acid diethylamide, narkobyznys (1).

\subsection{Rolnictwo}

To pole 3 hasła $(0,7 \%$ wszystkich haseł $)$ w 13 użyciach $(0,4 \%$ wszystkich użyć). Są to: farma (8), farmár (4), kovboj (1).

\subsection{Zoologia}

Również to pole tworzy 3 hasła ( $0,7 \%$ wszystkich haseł) w 13 poświadczeniach $(0,4 \%$ wszystkich użyć). Sa to: zoo (6), zoolog (2), zoologický (5).

\subsection{Polityka}

Jest to trzecie pole, w którym występują tylko 3 hasła $(0,7 \%$ wszystkich haseł) w 9 użyciach ( $0,3 \%$ wszystkich użyć). Są to: eGovernment/e-government 'stosowanie technologii informatycznych $\mathrm{w}$ administracji publicznej' (2), kongresmen (2), summit 'spotkanie najwyższych władz państwowych z różnych krajów’ (5).

\subsection{Nauki ścisłe i technika}

Ostatnie pole jest najmniejsze. Zwiera 2 hasła $(0,5 \%$ wszystkich haseł) w 3 poświadczeniach $(0,1 \%$ wszystkich użyć). Są to kód (2) i kódovaný (1).

\subsection{Przymiotniki odonimiczne}

Osobna grupe stanowia przymiotniki utworzone od nazw własnych. Nie są to anglicyzmy, ale wyrazy związane ze światem angloamerykańskim, utworzone od nazwy stanu U S A: texaský (2), $\mathrm{nazw}$ miast a mery kań ski c h: newyorský (3), washingtonský (1); i n n e: beatlesovský (1), hollywoodský (3), lasvegaský (1).

\section{Podsumowanie}

„Mladá fronta Dnes” to jedna z najlepiej sprzedających się gazet codziennych w Republice Czeskiej. Należy zatem przypuszczać, że pojawiajace się w tym periodyku wyrazy pochodzenia angielskiego weszły już na stałe do zasobu czeskiej leksyki lub staną się jego częścią w najbliższym czasie.

Analiza statystyczna zapożyczeń angielskich w badanej gazecie dowodzi, że 10 najczęstszych haseł to około $2 \%$ wszystkich haseł i około $23 \%$ wszystkich poświadczeń. Hapaxlegomena (tj. poświadczone tylko raz) stanowią około $40 \%$ wszystkich haseł i tylko około $6 \%$ całości poświadczeń $\mathrm{w}$ analizowanych numerach gazety.

Ze zgromadzonego materiału wynika, że anglicyzmy dotyczą w dużym stopniu słownictwa sportowego, sa one bardzo często używane (średnio przypada ponad 200 poświadczeń na każdy numer gazety). 
Warto tutaj zaznaczyć, że zebrany materiał ukazuje stan z roku 2009, czyli sprzed prawie dziesięciu lat. Od tego czasu pięciokrotnie mieliśmy możliwość obserwowania zmagań na igrzyskach olimpijskich (letnich i zimowych), na których wciąż pojawiają się nowe dyscypliny i związane z nimi słownictwo, najczęściej pochodzenia angielskiego. W związku z tym z dużym prawdopodobieństwem możemy stwierdzić, że dziś liczba anglicyzmów dotyczących sportu jest jeszcze większa.

Podobna sytuacja ma miejsce w przypadku innych dziedzin, np. komputerów i Internetu, urządzeń audiowizualnych, środków masowego przekazu, muzyki i subkultur, ekonomii i handlu czy transportu i budownictwa. We wszystkich wymienionych (oraz innych) dziedzinach język angielski wciąż wpływa (i najprawdopodobniej będzie wpływać) w znacznym stopniu na procesy nominacyjne nowych zjawisk i przedmiotów.

W przyszłości warto jeszcze raz zająć się problematyką anglicyzmów w „Mladá fronta Dnes”, aby stwierdzić, które z anglicyzmów (wyekscerpowanych z numerów opublikowanych w 2009 roku) są wciąż w użyciu.

\section{Literatura}

B a ń k o w s k i A., 2000, Etymologiczny słownik języka polskiego, t. 1, Kraków.

B u t 1 e r D., 1967, Koncepcje pola znaczeniowego, „Przegląd Humanistyczny”, nr 2, s. $41-59$

H a m $\mathrm{p} 1$ L., 2014, Odraz anglické lexikální jednotky »blue« $v$ českých neologizmech a počeštěném názvoslovi s využitím bázové modré barvy, „Bohemistyka”, nr 1, s. 78-86.

H u b á č e k J., 2003, Výběrový slovník českých slangů, Ostrava.

I m i oło I., 2001, Język czeskiej reklamy końca XX wieku, „Bohemistyka”, nr 2 , s. $153-169$.

K o ř e n s k ý J., 2003, Internacionalizace současných slovanských jazyků-možnost nebo nutnost?, Jazykovedný časopis", nr 1-2, s. 7-11.

K r a u s J. a kol., 2007, Nový akademický slovník cizich slov A-Ž, Praha.

Mańc z a k-W o hlfeld E., 1992, Analiza dekompozycyjna zapożyczeń angielskich w języku polskim, Kraków.
M a ń c z a k - W o h 1 fe ld E., 1995, Tendencje rozwojowe wspótczesnych zapożyczeń angielskich w języku polskim, Kraków.

M a ń c z a k - W o h 1 fe 1 d E. (red.), 2010, Słownik zapożyczeń angielskich w polszczyźnie, Warszawa.

M a r t i n c o v á O. a kol., 1998-2004, Nová slova v češtině. Slovník neologizmů. Díl $1-2$, Praha.

Michalska E., 2010, Vliv angličtiny na slovni zásobu češtiny po sametové revoluci v roce 1989, [w:] Odbicie ważnych wydarzeń historycznych w języku $i$ w literaturze czeskiej, red. M. Balowski, Poznań, s. 375-383.

N e k u l a M., 2004, Anglicismy v češtině, [w:] W. Viereck, K. Viereck, H. Ramisch, Atlas anglického jazyka, Praha, s. 259-277.

P is a rek W., 1967, Pojęcie pola znaczeniowego i jego użyteczność w badaniach stylistycznych, „Pamiętnik Literacki”, nr 2, s. 493-516.

R e j z e k J., 2001, Český etymologický slovnik, Voznice.

S v o b o d o v á D., 2007, Internacionalizace současné české slovni zásoby, Ostrava.

Svobodová D., 2010, Cizojazyčné neologizmy: mezi módností a standardem, [w:] Odbicie waznych wydarzeń historycznych w języku $i$ w literaturze czeskiej, red. M. Balowski, Poznań, s. 285-394.

S vo bodová D., 2015, Jazykové, psychologické a historicko-kulturni vlivy na adaptaci cizích slov, [w:] Doświadczanie codzienności w języku i w literaturze czeskiej, red. M. Balowski, Poznań, s. 375-382.

S v ob od ová D., 2016, Anglicismy v češtině: analýza adaptačnich vzorců, [w:] Chaos $i$ ład $w$ języku $i$ w literaturze czeskiej, red. M. Balowski, Poznań, s. 440-447.

S z c z e p a ń s k a E., 2004a, Niektóre tendencje w rozwoju języka czeskiego i polskiego, „Bohemistyka”, nr 1, s. 19-27.

S z c ze pań ska E., 2004b, Internacjonalizacja a anglicyzmy $w$ języku czeskim i polskim, „Bohemistyka”, nr 2, s. 96-104.

S z c z e p a ń s k a E., 2009, Procesy językowe w komunikacji językowej jako przejaw globalizacji języka, „Bohemistyka”, nr 1, s. 51-62.

T o k a r s k i R., 1984, Struktura pola znaczeniowego (studia językoznawcze), Warszawa.

W a s z a k o w a K., 2006, Onowych pracach Czeskiej Akademii Nauk poświęconych neologizmom, „Poradnik Językowy”, z. 6, s. 3-22. 